\title{
Citrobacter farmeri
}

National Cancer Institute

\section{Source}

National Cancer Institute. Citrobacterfarmeri. NCI Thesaurus. Code C86264.

A species of facultatively anaerobic, gram negative, rod shaped bacteria assigned to the phylum Proteobacteria. This species is motile by peritrichous flagella, citrate, indole and adonitol positive, hydrogen sulfide negative in Kliger's agar, phenylalanine negative and does not grow in KCN medium. C. farmeri is most commonly found in water, sewage, soil, and food and is an opportunistic, nosocomial pathogen. 